University of Wollongong

Research Online

Faculty of Social Sciences - Papers (Archive) Faculty of Arts, Social Sciences \& Humanities

$1-1-2018$

Labour Geographies of Workplace Restructuring: An Intra-Labour Analysis

Andrew T. Warren

University of Wollongong, awarren@uow.edu.au

Follow this and additional works at: https://ro.uow.edu.au/sspapers

Part of the Education Commons, and the Social and Behavioral Sciences Commons

Research Online is the open access institutional repository for the University of Wollongong. For further information contact the UOW Library: research-pubs@uow.edu.au 


\title{
Labour Geographies of Workplace Restructuring: An Intra-Labour Analysis
}

\author{
Abstract \\ Informed by labour geography's thrust to situate workers as active subjects of analysis, this article \\ examines lived experiences of restructuring at Australia's single largest industrial workplace. Drawing on \\ extended ethnographic research, the article traverses three restructuring outcomes faced by workers and \\ their families: (1) job retention; (2) redundancy; and (3) re-employment. Amid the turbulence and \\ uncertainty of a major workplace restructuring episode, workers' different lived experiences illuminate \\ uneven intra-labour power relations. As capitalist workplaces are re-organised and labour processes \\ redefined, more conflictual and divisive relationships often develop among groups of workers \\ differentially positioned within the hierarchical labour markets of large firms. Emphasising restructuring \\ episodes as generative contexts for grounded labour geographies research, the article develops \\ intra-labour agency as a critical analytical frame to explore more deeply the agency implications of \\ workplace structures, co-worker relationships, and social life matters that shape workers' capacities for \\ action inside and beyond workplaces. \\ Disciplines \\ Education | Social and Behavioral Sciences \\ Publication Details \\ Warren, A. (2019). Labour Geographies of Workplace Restructuring: An Intra-Labour Analysis. Antipode: a \\ radical journal of geography, 51 (2), 681-706.
}

This journal article is available at Research Online: https://ro.uow.edu.au/sspapers/4151 


\title{
Labour geographies of Workplace Restructuring: An Intra-Labour Analysis
}

Andrew Warren

School of Geography \& Sustainable Communities, University of Wollongong NSW Australia 2522

\begin{abstract}
Informed by labour geography's thrust to situate workers as active subjects of analysis, this articles examines lived experiences of restructuring at Australia's single largest industrial workplace. Drawing on extended ethnographic research, the article traverses three restructuring outcomes faced by workers and their families: 1) job retention 2) redundancy, and 3) re-employment. Amid the turbulence and uncertainty of a major workplace restructuring episode, worker's different lived experiences illuminate uneven intra-labour power relations. As capitalist workplaces are re-organised and labour processes redefined more conflictual and divisive relationships often develop among groups of workers differentially positioned within the hierarchical labour markets of large firms. Emphasising restructuring episodes as generative contexts for grounded labour geographies research, the article develops intra-labour agency as a critical analytical frame to explore more deeply the agency implications of workplace structures, co-worker relationships, and social life matters that shape worker's capacities for action inside and beyond workplaces.
\end{abstract}

\section{Resumen}

Informado por el impulso de la geografía del trabajo para situar a los trabajadores como sujetos activos de análisis, este artículo examina las experiencias vividas de reestructuración en el más grande lugar de trabajo industrial de Australia. Basándose en la investigación etnográfica extendida, el artículo atraviesa tres resultados de reestructuración que enfrentan los trabajadores y sus familias: 1) retención de empleo 2) redundancia y 3) reempleo. En medio de la turbulencia e incertidumbre de un importante episodio de reestructuración en el lugar de trabajo, las diferentes experiencias vividas de los trabajadores iluminan las desiguales relaciones de poder intralaborales. A medida que los lugares de trabajo capitalistas se reorganizan y los procesos laborales se redefinen, las relaciones conflictivas y divisivas se desarrollan a menudo entre grupos de trabajadores posicionados diferencialmente dentro de los mercados laborales jerárquicos de las grandes empresas. Al enfatizar los episodios de reestructuración como contextos generativos para la investigación de geografías laborales fundamentadas, el artículo desarrolla la agencia intralaboral como un marco analítico crítico para explorar más profundamente las implicaciones institucionales de las estructuras del lugar de trabajo, las relaciones del compañero de trabajo y la vida social que moldean las capacidades de acción de los trabajadores dentro y más allá de los lugares de trabajo. 


\section{Introduction}

It's August 2011. Australia's economy is in the midst of a 'mining boom', spurred by China's demand for mineral resources. Inflated commodity prices and policy settings of other nations have driven the Australian dollar to parity with its U.S. counterpart. While mining and financial sectors are in a boom, manufacturing is near bust. In a press release Australia's second largest manufacturing firm BlueScope - announces plans for 'major restructuring'. ${ }^{1}$ A spin-off company of BHP ('The Big Australian'), BluesScope explains it will mothball a blast furnace and cease exports from its 'flagship' Port Kembla Steelworks (PKS) in the 'old' industrial Illawarra region. Macroeconomic factors are blamed for a profitability crisis: a high Australian dollar, expensive raw materials, competitive pressures, and weak demand for slab steel. To help establish new conditions for accumulation 1000 full-time jobs are slated for redundancy, $25 \%$ of the direct workforce. Another 220 contractors will also lose employment without compensation. Having dominated the local labour market since the 1930s, the scale of restructuring creates anxiety and uncertainty anew. Union leaders attempt to mobilise political support by rescaling debate beyond steel and the Illawarra, questioning whether Australia wants to 'value-add to its natural resources' and be a 'country that still makes things' (Gibson et al. 2012:109). The costs of restructuring are quantified in job losses and flow-on effects for the regional economy. Less easily measured are the lived experiences of affected workers and families.

This article takes a labour-centred approach to the analysis of a major restructuring episode at Australia's largest industrial workplace. ${ }^{2}$ It's now two decades since Herod (1997:25) outlined labour geography as a conceptual-political project, calling attention to working people's 'capacity for proactive geographical praxis'. Critiquing Marxist and neoclassical accounts of economic change for one-sidedly emphasising capital as the dominant subject, labour geography has developed analytical perspectives cognisant of labour's abilities to shape the spatiality of capitalism. Far from an isolated endeavour, labour geography has included reciprocal intellectual trade with labour history and industrial relations (Rainnie et al. 2007; Ellem 2016; Featherstone and Griffin 2016), helping to build approaches to labour studies that view geography as more than descriptive backdrop.

A first generation of labour geography research often prioritised effective actions by unions, revealing labour's collective and institutional power under capitalism (Herod 2001). But focusing on leading-edges of the labour movement drowned-out dialogue with studies of the failed actions, shortlived gains, narrow-mindedness, and uneven bargaining outcomes (Peck 2013). Critical reviews urged for a move beyond union-management relations and more robust theorising of labour agency, particularly its geographic biases, social efficacy, and structural constraints (Castree 2007; Mitchell 2011). Responding to limitations and a shifting political economy of accumulation, labour geography has since pluralised across a wider range of labouring contexts and conditions (Hastings 2016; Strauss 2017). In the last decade, research has sought to ensure theory claims around labour agency are firmly 
based in the concrete realities of contemporary work and employment (Coe and Jordhus-Lier 2011). This article adjoins ongoing efforts to develop more critical and contextualised labour geographies. Re-emphasising capitalist restructuring as a generative political and analytical context for labourcentred research (cf. Siemiatycki 2012; Werner 2012; Peck 2013; Ince et al. 2015), the analysis examines the lived experiences of restructuring for 27 workers differentially positioned in the flagship workplace of a multinational steel firm.

In tracing labour geographies of workplace restructuring, the paper's aim is two-fold. First, as labour geographers continue to engage with questions of how to theorise and position worker agency under capitalism, the analysis focuses on intra-labour politics and power relationships within a workforce. Specifically, I develop intra-labour agency as an analytical lens to direct critical attention to the structures, power relationships, and uneven social capacities for action within labour (cf. Hudson 2001). In the case analysed, restructuring was a typically disruptive, prolonged process that incited more conflictual and divisive workplace relationships. Within a hierarchical internal labour market fractious relations emerged between a more secure 'core' of older salaried employees clustered in production and maintenance works planning, and younger insecure employees on the maintenance 'periphery'. A once powerful unionism, built-on a common set of lived experiences, was disdained by many younger workers 'for serving the interests of core groups and forgetting insecure contractors' (Chad, 2015). Over time intra-labour conflict foreclosed opportunities to (re)build solidarity with a more flexibly organised, self-interested, and polarised workplace emerging from restructuring.

Second, around an intra-labour focus I draw an extended spatio-temporal view of working life in a context of mass-redundancy, transformation of labour processes, and social turbulence. Two related bodies of research, often situated outside 'agency-centred' labour geographies, inform the analysis. One is influential work emerging from the 1970s and 1980s that conceptualises capitalist restructuring as a choreographed and contested process of transforming capital-labour-state relations to support an accumulation strategy (Bluestone and Harrison 1982; Harvey 1982; Massey 1984). The other is parallel studies of contemporary plant closures that illustrate the personal challenges and 'patchiness' of re-employment outcomes for displaced workers in 'old' industrial places (Pike 2005; Gardiner et al. 2009; Bailey et al. 2014). I examine working people's differentiated experiences of the 'restructuring present' (Peck 2013:112), drawing-on ethnographic research mobilised between a sprawling industrial workplace and wider community.

The remaining article is organised as follows. Next, I outline relational and spatialised conceptions of agency (Katz 2004; Coe and Jordhus-Lier 2011), before developing intra-labour agency as a lens to foreground workplace power relations and their effects on worker agency. I then position the case study, emphasising the relevance of restructuring episodes and the workplace scale for grounded labour geographies. After outlining the ethnographic research approach, empirical 
analysis is presented. I begin by historicising labour relations at PKS with 'brutal restructuring' in the 1980s, overlaid with changes to national IR laws, eroding union power and deepening intra-labour divisions. Analysis of the restructuring present is organised around three worker-centred outcomes: 1) employment retention, 2) redundancy, and 3) re-employment. I reveal the uneven lived experiences of restructuring at the point of production alongside intra-labour fracturing and social life matters that shape individual expressions of agency. The article concludes arguing that while intra-labour analyses can't account for the root cause of inequities in workplaces, intra-labour agency is a useful frame to help explore the uneven power dynamics and different capacities for action within labour itself.

\section{Conceptualising agency in labour geography}

Labour geography is associated with investigating the power of working people to shape economic spaces, improve material conditions, and sustain social life (Herod 2001; 2018). To develop an approach for examining the lived experiences of workplace restructuring and power relationships active within labour I draw on the combined frameworks of Katz (2004) and Coe and Jordhus-Lier (2011), which offer conceptualisations of agency informed by relational ontological registers. Working from the viewpoint of social reproduction, Katz's (2004:241) longitudinal study of children's experiences of economic restructuring builds three 'fluid and overlapping categories' of social agency: resilience, reworking, and resistance. The typology embraces strategies and actions 'carried out at a range of scales and by a number of differently situated actors' (Katz 2004:241). Resilience concerns the coping strategies - what Katz (2004:242) calls 'restorative and strengthening acts' - that help people resourcefully 'make-do' with difficult situations. For instance, households impacted by job loss may reduce consumer spending to cope with lost income (Dobbins et al. 2013). Yet, because resilient acts are often reactive and don't directly challenge exploitative social relations they can 'support the general trajectory of the developments that necessitated these acts in the first place' (Katz 2004:246). Despite limitations, resilient acts become socially necessary during a crisis and potentially establish foundations for more progressive acts at another time or place.

The second category, reworking, includes actions that aim to alter 'the conditions of people's existence to enable more workable lives' (Katz 2004:247). Reworking is captured in efforts to directly and materially improve livelihoods. In the context of paid work this may involve efforts to improve employment terms (e.g. permanency, contract length) and/or conditions (e.g. wages, safety improvements). Reworking relies on more conscious, proactive responses to a situation as actions 'bend' structural constraints to generate a more positive outcome (Cumbers et al. 2010). But like resilience, reworking acts don't directly challenge capitalistic social relations. By contrast, resistance includes openly oppositional actions that seek to transcend, 'historically and geographically specific conditions of oppression and exploitation' (Katz 2004:251). Resistance comprises attempts to recover 
control of labour power across the whole of social life, for instance, by instituting non-monetised exchange relations in a community. But resistant acts demand high degrees of oppositional consciousness as actions face barriers relating to scaling-up, instituting alternative governance, and dealing with questions of legality and policing.

The typology Katz's (2004) offers helps practically identify and organise social agency around three relational categories. But whether categorisation relates to the initial objectives of actions or the social outcomes achieved is unclear. To treat labour agency in a more discerning and spatialised way, Coe and Jordhus-Lier (2011) develop a framework of 'constrained labour agency' that coordinates analysis at two levels. First, worker agency must be 'unpacked' along the 'spatial and temporal dimensions' that shape its effectiveness (Coe and Jordhus-Lier 2011:221). This involves assessing agency in relation to core geographical concepts of space, place, scale and time; concepts deeply implicated in the social regulation of labour markets (Peck 1996). Second, agency needs to be reembedded into the key arenas 'in which all workers are inevitably, but differentially, positioned' (Coe and Jordhus-Lier 2011:228). To help re-embed labour agency four institutional contexts are prioritised: i. the organisation of capital, ii. structures of the state, iii. community politics, and iv. labour market intermediaries. These social arenas capture the actors, power relations, and institutions 'fundamental to labour and its political organizations' (Coe and Jordhus-Lier 2011:221). Together Katz (2004) and Coe and Jordhus-Lier (2011) offer labour geographer's a process-based approach to identify and distinguish the ways working people shape capitalism while recognising agency - as a foundation for power - is unevenly distributed, constrained, and not always progressive.

More specifically for this analysis of restructuring in a hierarchical workplace situated in an old industrial community, lived experiences of economic change not only illuminate unequal power relations between labour, capital, and the state (cf. Pike 2005) but expose divisions, disparities, competition, and conflict within the workforce. In short, labour's 'internal fracturing', as Hudson (2001:218) identifies, often supports capital accumulation by inciting self-interest and subduing labour's collective solidarity (Gough 2010). Thus to fully embed agency in 'the social relations that shape and condition its variegated forms of expression' (MacKinnon 2017:72), I foreground the uneven experiences of restructuring, interrogating intra-labour politics and power relations active within the diverse workforce of an integrated steelworks.

\section{Intra-labour agency}

Economic geographers have long theorised the conflictual and asymmetrical power relations between capital and labour (Harvey 1982), detailing how political forces of the state often tip the balance in bargaining outcomes (Weller 2007). Labour's agency is informed by configurations of capital, structures of the state, organised labour strategies, and intermediaries acting as conduits between 
employers and employees (Coe and Jordhus-Lier 2011). Equally, the labour process relations of workers themselves, grounded in everyday spatialities such as workplaces and households, strongly influence value creation, labour politics, and action-taking (Castree et al. 2004). Analytical attention to intra-labour dynamics is crucial for improving understandings of the changing lived experiences of work and the unequal capacities for workers and communities to effectively respond to critical events such as restructuring in a place of employment (cf. Gardiner et al. 2009; Hastings 2016).

Despite their relevance, the intra-labour politics that play out daily in spaces and places of work have not been a central concern for labour geographers and their agency theorising (Gough 2010; Werner 2012; Gutelius 2015; Ince et al. 2015 are exceptions). Building on calls to ground and clearly delineate the forms of worker agency (Cumbers et al. 2016; MacKinnon 2017), I seek to mobilise intra-labour agency as a lens to critically examine the unequal capacities and expressions of agency among workers living through the disruptive reorganisation of their workplace and jobs. Through the empirical analysis that follows I unpack intra-labour agency around three broad 'shaping' dynamics encountered in the restructuring at PKS. These include the workplace structures positioning workers in hierarchies and divisions of labour in pursuit of accumulation; prevailing intra-labour relationships among employees in the workplace, and social life matters that regulate the ability of individual workers to take certain courses of action such as striking or accepting voluntary redundancy (figure 1).

\section{$<$ Figure 1 here $>$}

At the point of production, intra-labour divisions in workplaces are instituted by employers seeking the efficient completion of tasks to generate surplus value. But the success and reproduction of workplace regimes necessitates a degree of labour 'buy-in' (Burawoy 1979; Rutherford 2010). The workplace dynamics that shape intra-labour agency include associations of tasks, skills, technologies, and work conditions in the labour process; the authority of job positions; work schedules and intensities; unionisation and workplace legislation; capital (dis)investment, and influence in the wider community (Pike 2005; MacKinnon 2017). Positioning in workplace hierarchies or division of labour generates and reproduces different practices, capacities, and relationships: seniority, subordination, control, responsibility, collaboration (Massey 1984; McDowell 1991; Carr 2017). In this sense intralabour agency can help elaborate the effects of workplace structures for incentivising cooperation or creating fracture-lines that lead to conflict (Hudson 2001). Workplace structures are a key dynamic to the expression of agency as they inform individual capacities to act vis-à-vis constraining internal orders, rules, regimes, and power relationships.

Second, co-worker relationships in workplaces shape agency by impacting attitudes towards work, alliances, identities, and the likelihood of engaging in collective action. As Mehrotra (2017:263) demonstrates in her study of Dalit female workers in India, 'capitalist accumulation and labour suppression are helped by the nature of intra-labour relations, which are fraught with everyday 
altercations and tensions' (emphasis added). Workplaces are a key spatiality for labour politics, both in terms of wages and relationships among workers with propinquity (Castree et al. 2004). At PKS, conflictual relationships among workers of different generations in the hot strip mill damaged intralabour trust and productivity. Resulting dysfunction exposed several employees to forced redundancy as 'under-performing' work crews were targeted for downsizing. Capitalist workplaces aren't equitable social arenas and co-worker relationships are regularly stress-tested. Through extended ethnographic research I trace intra-labour relationships over a spectrum: from a state of solidarity based on collegiality, trust, and collective interest to antagonism defined by conflict, distrust, and self-interest. I examine how intra-labour relations influence expressions of agency as restructuring unfurls in a stratified workplace with reduced union legitimacy and power.

The third shaping dynamic of intra-labour agency articulated at PKS concerns the 'life matters' that differentiate workers as socio-spatial actors and determine individual abilities to pursue certain actions. While participants share a commonality of interests as paid workers in PKS, they embody a variety of other social identities, responsibilities, and life experiences that demarcate. For instance, the ability for several retrenched workers to leave the Illawarra region to find new employment was socially inconceivable due to localised family support networks that helped raise their young children. As feminist geographers have long argued, capitalist production (in workplaces) and social reproduction (in households) are interdependent with most labour in the home being unpaid and performed by women (Hanson and Pratt 1988; McDowell 1991). Beyond PKS, the analysis considers how social life (childcare, divisions of household labour, age, wealth, education, and place attachments) informs different experiences and response to restructuring.

Intra-labour agency is thus deployed as a frame to help explore more deeply the uneven lived experiences of workplace restructuring; a political-economic process intending to redesign work processes, relationships, and employment conditions. Empirical insights largely focus on intra-labour agency as varied individual actions within a stratified workplace. Under Katz's (2004) typology the intra-labour agency discussed encompasses resilient and reworking acts, illustrating the 'highly uneven political possibilities' facing working people (Coe and Jordhus-Lier 2011:219). The experiences examined relate to personal stories of restructuring but offer general insights for labour geographers, including on the challenges facing organised labour movements that must sustain a sense of collective purpose over the divisive effects of workplace regimes, intra-worker polarisation, and diverse subjective experiences of work. Having made a case for analysing intra-labour agency I now position the empirical case in relation to labour geographies of the restructuring present.

\section{Labour geographies and the place of workers}


Labour geography's empirical catalogue now includes a broad range of social actors, locations, and occupations. One expanding area of critical research involves positioning labour, their role in value creation/capture, and agency in relation to globally fragmented production systems (Gutelius 2015). Using global production network (GPN) and global value chain (GVC) approaches studies have explored the employment of migrant labour (Buckley et al. 2016) - the "embodiment of global integrations' (Ellen-Smith and Winders 2008:60) - and exposed complex relationships of opportunity and exploitation in the Global South (Werner 2012; Carswell and De Neve 2013). New spatial divisions of labour and industry dis/investment have inspired scrutiny of moralistic questions around how decisions and actions of workers, firms, and states made in a given time and place can have major consequences for distant communities (Hastings 2016). In short, global approaches have illustrated the major constraints facing working people, including how local places and labour markets are attached to a world of uneven flows, structures, and power relations (Bair and Werner 2017).

Amid capitalism's global economic hegemony, cases of restructuring have re-emerged as important contexts for labour geographers to investigate. Globally, capitalist restructuring continues to drive 'transformation in the employment relationship... with important economic and social repercussions' (ILO 2015:13). Recent analyses of restructuring schemes have highlighted how workers become pressured and obligated into making concessions and complying with capital to 'save' and 'secure' jobs (Siemiatycki 2012), questioning unionised labour's ability to counter the global neoliberal landscape (Cumbers et al. 2016). Joined to formative research from the 1980s, contemporary studies also re-affirm the contentious, often exclusionary politics, bound-up in defending jobs in local places gripped by structural change (Cumbers et al. 2010; Sweeney and Holmes 2013; Gialis and Herod 2014). Parochial campaigns to protect jobs - often fed by populist politics - have involved mobilising ugly discourses that hamper development of transnational solidarities (Ince et al. 2015). Globally-oriented analyses of restructuring help contextualise and deromanticise labour's agency while the need also remains to engage worker's experiences 'up-close' within daily spaces and places of labouring (Hastings and MacKinnon 2017).

This paper adds to recent labour geographies of restructuring in two ways. First, the extended ethnographic approach focuses analysis on intra-labour agency and dynamics of accumulation, power, exploitation, cooperation, and conflict. Such approaches and scales of analysis are under-represented in recent studies that situate labour, its agency potential and constraints, in global context. Placing labour globally is vital - including for theorising uneven development - but workplaces also remain significant socio-spatial arenas where labour markets and processes are grounded (Rutherford 2010), life matters negotiated, and agency 'exercised and expressed on a day-to-day basis' (Hastings and MacKinnon 2017:105). Second, I centre the lived experiences of workers and their families, contrasting most restructuring studies that focus on union-management relations. Such approaches map 
the shifting structural and institutional terrain for organised labour but offer limited insights into lived experiences of change over time. For many workers and families restructuring is a stressful and uncertain process, unevenly impacting tasks, jobs, income, morale, and life. My goal here is a contribution to unpacking some of the 'micro-politics of power and geographies of struggle within' labour (Brogan and Tufts 2017:3). Next, I outline the research methodology before empirical sections trace worker's uneven experiences of restructuring at PKS and bring intra-labour agency to the fore.

\section{Methodology}

Empirical research for the article emerged through personal connections to PKS. My father completed a trade in the plant during 1973 (machine fitter) before transitioning to a permanent job. After redundancy in 1983 he began working back at PKS in 2006, employed casually with a contract firm performing plant maintenance. As restructuring began in late 2011, termination of employment was signalled when the phone stopped ringing. The livelihoods of other relatives and close friends were also directly affected, including several supporting young families, repaying mortgages, and holding 'deep attachments to place' (Hudson and Sadler 1986:302). Participant recruitment began immediately following the announcement of restructuring with personal contacts and word-of-mouth snow-balling enlisting 27 workers (with 51 dependents). The group consisted of 22 men and five women, reflecting the overall gender break-up of PKS where $16 \%$ of employees are women (table 1).

\section{$<$ Table 1 here $>$}

The ethnographic approach was informed by a concern with worker's experiences of restructuring. Covering a six year period (2011-2016) the research unfolded in two overlapping stages. Initial meetings were held with workers before semi-structured interviews captured personal stories on the changes unfolding at PKS. Further interviews were held throughout the study to capture specific insights on major events (e.g. changes in job conditions, redundancy notifications, job searching). A total of 143 interviews were conducted with workers; 89 involved family members such as partners. Having built rapport, participant observation then helped examine personal experiences in detail. For an initial 20 months, participant observation occurred outside the workplace at regular 'catch-ups', lasting several hours, in family homes and community spaces (public parks, sporting events, local clubs, and cafes). Union meetings, public rallies, and celebrations for retrenched workers were also attended. Participant observation in the plant was facilitated in 2013 by maintenance workers who moved around performing specific tasks (e.g. servicing conveyors, welding, machinery repair). Workplace access enabled close observation of work spaces, hierarchies, and intra-labour interactions.

To contextualise working life at PKS archival research was undertaken in the University of Wollongong's Oral History Collection with 21 interviews with former steelworkers transcribed, spanning 1935 to 1985. Data was also sourced from the Australian Bureau of Statistics (ABS) and 
Illawarra Regional Information Service (IRIS), helping develop a clearer understanding of PKS' changing significance to the regional economy. Annual financial reports (2003-2017) then provided quantitative insights on company performance, investments, asset write-downs, and future planning. Data in such reports were compared to public statements and participant narratives. Written notes were made in a fieldbook during participant observation sessions and interviews, acting as a form of crosstabulation for emergent themes. The notes reflected on initial ideas, problems encountered, details lacking, and points needing clarification. All interviews were professionally transcribed, and with the field notes, were interpreted using a narrative analysis. The aim was to utilise narratives as illustrative cases of the restructuring process with analysis being sensitive to personal experiences while building general themes across the group (cf. Warren 2014). Pseudonyms are used throughout the article and some details are discussed in general terms to maintain workers' privacy. ${ }^{4}$

\section{Labour and restructuring in historical context}

The experiences of 'present' restructuring are inevitably linked to previous episodes (cf. Bluestone and Harrison 1982; Massey 1984). Until the early 1980s a densely unionised workforce prevailed at PKS with three key factors empowering the labour movement. First, Australia's IR system was overseen by the Conciliation and Arbitration Court (CAC), a progressive regulatory space that settled industrial disputes based on 'fair and reasonable... economic needs of employees rather than a market for labour' (CAC Act 1904, np). The CAC formalised the institutional power of unions via mandatory collective bargaining (Weller 2007). Second, a difficult and dangerous labour process, and ruthlessness of BHP, generated strong labour solidarity and community-wide support for unions (Eklund 2002). By the late 1930s serious accidents and deaths were so common around open-hearth production PKS was known as 'the bloodhouse'. Through membership of the Federated Ironworkers of Australia (FIA), Australian Workers Union (AWU), and South Coast Labour Council (SCLC) Illawarra workers led campaigns to improve workplace safety laws, reduce the working day, and gain paid leave benefits.

Third, the local labour movement was energised by international migration to the region after WWII. As BHP enjoyed a near-monopoly under Australia's Industries Preservation Act (1921) an expanding PKS needed labour in numbers beyond what the local population could supply. Inmigration from non-Anglo nations (Macedonia, Greece, Turkey, Italy) added diversity to the region's working-class (Haughton 1990). By 1975 workers from 68 different nations laboured in PKS; 50\% from non-English speaking backgrounds. New migrants often filled low-skilled positions at the bottom of pay-scales (cf. McDowell et al. 2009), yet joined unions in large numbers ensuring major voting power. A socially progressive unionism was channelled through cultural diversity. Collective actions helped rework living standards, enrolling communities in initiatives ranging from funding local health services to supporting campaigns from Aboriginal groups to secure housing and employment (Eklund 
2002). With PKS employing 40\% of the region's workforce the Illawarra became a geographical heartland of Australian unionism.

But when global turbulence reached Australia in the late 1970s the ground on which labour organised shifted. Neoliberalisation reshaped the national accumulation strategy and BHP executives embarked on major rationalisation of steel-making at PKS. To boost productivity investment was made in new steel-making technologies. Two continuous slab casters, commissioned in 1978 and 1980, enabled production to be organised in tight alignment with market demand. This was automation for accumulation and technological change initiated major intra-labour changes. As one veteran employee reflected, 'the production process was transformed and so were relationships throughout the workplace' (James, 2014). Retiring and voluntarily retrenched blue-collar workers were replaced by white-collar labour and the number of tertiary qualified employees increased 31\% between 1975 and 1980 (Burrows 2012). Blue-collar workers, from production to 'in-house' maintenance, 'relied on over-time and shift work to make good money’ (Mick, 2011), endearing high levels of unity. Post1980s, higher numbers of white-collar 'staff' - largely production-oriented - received salaries negotiated individually. Structural adjustment had significant intra-labour implications:

I started in [19]78 as the BOS technologies arrived and that restructure was bloody brutal. I maintained heavy machinery and there was healthy respect and cooperation from white shirts [managers] to blue overalls. It was very different after. A clinical, cut-throat regime began. You started seeing arguments over workloads and management styles. Unions and their agenda caused animosity in the workforce too. From the maintenance side, we became second class citizens with a growing army of contractors'. (Harry, 2013)

New workplace hierarchies weakened union density and fractured labour's collective unity. Capitalintensiveness in the workplace also dovetailed with major regulatory changes nationally.

In 1981 a conservative federal government pressured the CAC to halt increasing wages with inflation. Concurrently competition in slab steel increased as tariff reduction began (Haughton 1990). Forced redundancies at PKS started in 1982 with a national recession providing the impulse and camouflage for a savage program of job cuts. By mid-1984 14000 workers had been retrenched with the regional unemployment rate increasing 67\% (Eklund 2002). Final outcomes of the restructuring also spurred new intra-labour factions. Unions upheld a 'last on-first off' retrenchment policy that favoured age over skill and discriminated against women who had recently gained jobs after winning a sex discrimination legal case against BHP's recruitment procedures (see Tonkin 2000).

When restructuring concluded at PKS a new Labor government (1983-1996) had progressed towards an IR system based on 'enterprise bargaining' and a new social contract - the 'Prices and Incomes Accord' - between the state, capital, and unions. Famously, the accord moderated unions' wage demands on the belief market-based reforms would drive new economic growth to benefit all (cf. 
Bluestone and Harrison 1982). In reality, the new IR framework linked wages to productivity gains within enterprises. Neoliberalisation of the employment relationship ramped-up with the Howard government (1996-2007) and Workplace Relations Act (1996), enabling individual contracts economywide (Cooper and Ellem 2008). At PKS this 'brutal' 1980s restructuring produced lasting effects, diluting union power and dividing the workforce into more isolated units. As one employee stated: 'We're separated around specific performance goals and levels. There's no much solidarity left in the place' (Paul, 2014). Despite a proud legacy of progressive unionism, a narrower self-interest became more pervasive (Gough 2010). This historical conjuncture is vital context (cf. Featherstone and Griffin 2016), as present restructuring unfurled in a workplace with weakened intra-labour unity, constraining hierarchies, and poor job prospects locally for steelworkers facing unemployment.

\section{Restructuring and job retention}

This section traces the experiences of workers who maintained employment post-restructuring. The 13 participants who retained jobs in a leaner workplace (11 men, two women) were employed in technical trades or engineering roles, working at PKS for an average of 20 years. While endorsing the importance of technical skills and experience for shaping positive outcomes amid downsizing in a capitalist workplace (Bailey et al. 2014), workers also revealed how intra-labour dynamics supported career progression and job retention. Judy, a production technician, elaborated:

I've always made a point of keeping good working relationships... right along the chain. That's so important. Even when I don't agree with someone, I handle that in a certain way. Resolve and move one. You earn trust and respect that way, from the shopfloor to other line managers, right the way up. I've earned a [reputation], in different sections, for being a good people person who can work in and lead a team. Two high-level managers have been mentors and with a good work ethic, it's helped with promotion to supervisor roles [2009]. ... I'm always telling my work crew that [workplace] relationships are a big part of doing your job. (2012)

In sections of PKS where 'redundancy quotas' were instituted job retention was commonly influenced by prevailing relationships among workers differentially positioned in hierarchies. Workplace regimes were strategically navigated using interpersonal skills to foster reputations as a 'problem-solver', 'good communicator', and 'reliable worker' (David, 2013). Combinations of technical knowledge, internal positioning, and reputation-building along chains of command underpinned job retention, illustrating intra-labour agency corresponding to Katz's (2004) category of 'reworking'.

Contrasting outcomes for other workers provided further insights into intra-labour unevenness. David and Craig completed electrical trades together in 2006, each moving to 'operator' roles in the hot strip mill, planning maintenance and repair works. After several years of 'good performance' organising maintenance and repair, David transferred to a salaried 'staff' position in the coated 
products section called 'Springhill'. Craig, meanwhile, remained 'stuck' with multiple transfer applications rejected by line and section managers. Craig outlined the 'difficult relationship' shared with managers (themselves progressing from operator and works planning roles) and several 'waged' maintenance employees he scheduled jobs for. After a safety incident in 2010, blamed on Craig's 'arrogance', co-worker relationships deteriorated. Craig was since viewed by colleagues as 'opinionated', 'difficult', and 'a bit of an outcast' (Research notes, 2012).

The difference between David's upward mobility and Craig's immobility became telling. Reduced steel output from 2012 resulted in a high number of redundancies from the hot strip mill. At Springhill, the most profitable division of PKS, there were few redundancies. David emerged from restructuring in a promoted staffing role. Craig experienced retrenchment:

We both started in 2003 just before maintenance jobs came through contractors. We were the last [cohort] to be employed directly, giving us early supervision experience. Some operator jobs came up. Preparing maintenance shutdowns, budgeting costs, organising and planning work orders. I got on real well with [section manager] but Craig and some others butted heads. They screwed-up procedures; got a reputation for being difficult. That's a big problem. If you're not valued in your work section you're a target. I built good relationships, had support and the opportunities came-up. Managers kept an eye out for a transfer [to Springhill], where everyone wants to be. We handle coated steel products, all high-value and had no forced redundancies. Craig's section was smashed. He lost his job. (2013)

Cooperation and compliance with employees in positions of power, horizontally and vertically, was crucial to intra-labour agency. But beyond PKS, partners also enabled upward mobility, coping with 'longer hours and more time away from home' (David, 2014). Judy and David reworked employment into roles with higher salaries and material benefits. Despite identical qualifications, Craig's agency was constrained by a reputation for 'difficult' behaviour and rigid workplace structures (cf. Coe and Jordhus-Lier 2011). Such experiences reveal how intra-labour agency is shaped by co-worker relationships, workplace structures, and wider social factors.

Intra-labour dynamics informed experiences of the restructuring in other ways too. In the year after the first redundancies occurred steel prices, revenue, and profits remained lower than predicted. New concerns and anxieties arose over further job losses and rumours of total plant closure (cf. Stroud and Fairbrother 2012). The stress and uncertainty had material, intra-labour effects:

Morale's been smashed. I'm genuinely worried about my job, yeah. All this depressing talk. Crews are fighting and management along the line have changed their tune. Old managers came from the shopfloor but the new ones have a fancy degree with little shopfloor experience. Straight to staff ... Jobs are planned without consulting experienced steelmakers. My shift pattern's changed three times in three months. I've gone from day [shift] to nights to split shifts 
to four-on-four off [12 hour shifts]. My old work crew has been split and there's a lot of anger around. It just sucks the life out of you. (James, 2013)

Without a clear endpoint, restructuring was experienced as a series of undesirable changes that fractured morale, work crews, shift patterns, and lifestyles. Shopfloor workers criticised new managers whom they felt contributed to worsening morale and productivity. But co-worker relations also entered into 'a really bad state' with customary teams divided and 'shift patterns changed on a whim' (Chris, 2014). Reorganised production in the workplace also impacted families juggling childcare, schooling, and relationships around unusual shifts and rostering. Well-paid jobs were retained but there were trade-offs: daily frustrations, stresses, and social costs.

The prolonged restructuring led to actions that further eroded intra-labour unity. A group of maintenance workers, for example, began a practice of logging complaints against operators and job planners when work procedures weren't strictly followed. Tools were 'downed' over relatively minor issues, from a missing line of high-visibility tape on a stairwell to a faulty air-conditioner in a crib room. Under safety rules such actions triggered investigations, stalling works completion and impacting the incomes of 'salary staff' when productivity targets weren't met. Out of such interactions grew deeper animosity among wage and salary employees. Mundane actions were a coping strategy for those feeling disenfranchised with the restructuring. However, morale problems were made worse as vestiges of workforce cooperation evaporated and in-time placed 25 jobs at risk when senior managers cited the dysfunction as a reason for increasing the use of maintenance subcontractors. Consistent with approaching agency as an analytical, political, and moral issue (Hastings 2016), an intra-labour focus helps articulate the different capacities for, and constraints upon, individual workers seeking to navigate overarching workplace structures, power relations, and social life matters to affect positive change. Attention now turns to the lived experiences of redundancy.

\section{Restructuring and redundancy}

In Australian workplaces, redundancy must be justified on the basis of a firm's poor financial performance; use of labour-saving technologies; re-arrangement/relocation of production or an acquisition/merger. Employers are legally obligated to explore alternatives to job loss, including redeployment, reduced hours, and job sharing arrangements. Genuine redundancies equate to a job no longer needing to be performed inclusive of the job title, wages, tasks, and location. ${ }^{5}$ Initial plans to restructure PKS triggered an arbitration process between the company and unions (AWU and Electrical Trades Union) via Australia's Fair Work Commission. Unions argued for reduced job losses due to labour's contribution to improved productivity and underlying financial strength of the firm, which reported revenues in 2008 and 2009, exceeding US\$10 billion - 55\% from domestic operations. Mediation reduced total redundancies to around 850 with policy responses to the mass-redundancies 
including supply-side and demand-side initiatives (cf. Dobbins et al. 2013). The federal government provided $\mathrm{A} \$ 35 \mathrm{M}$ for worker retraining and counselling, coupled to a 'matching' grant scheme to support Illawarra-based firms expand and re-employ ex-steelworkers. In sections of PKS being downsized employees faced two versions of redundancy: voluntary (VR) and forced (FR).

\section{Voluntary redundancy}

A VR process began with management's call for 'expressions of interest' (EOI). Direct 'waged' employees received VR payments negotiated by unions and enshrined in enterprise bargaining agreements (EBA). Salaried staff had financial severance packages spelled-out in their employment contracts. Both groups received payments based on service-time and one-off bonuses up to A $\$ 12500$. Waged and salaried employees received higher redundancy payments vis-à-vis full-time workers employed indirectly by contract firms. This latter cohort were often covered by general industry Awards not an EBA (table 2). Lastly, casual employees received no severance pay as 'the work simply dried-up' (Gary, 2012). Five participants took VR (mean age of 55), with four men within three years of 'planned retirement'. For Melissa (43), the timing of restructuring was opportune as her family had decided to leave the Illawarra before VRs were offered. Severance money from 15 years of direct employment 'was a good kick-start in a new place' (Melissa, 2012). The others, directly employed for an average of 29 years, were mortgage free and had few dependents to support. Their redundancy packages totalled up to A $\$ 320000$.

$\langle$ Table 2 here $>$

With the timing of restructuring socially agreeable, VR enabled earlier, more financially secure retirements. Rod, a line manager in the mothballed blast furnace, turned 60 only weeks before his EOI for VR was accepted. Australian legislation allowed tax-free access to his pension fund with redundancy payments also exempt from income tax. VR added substantial depth to a retirement pool: I really wish it [restructuring] wasn't this severe. It's terrible news for some younger workers and contractors. There's obviously lots of people worried and hurting. But for us, the VR is a golden handshake. I've been here 35 years, so now I get an earlier retirement 300 grand better. I'll enjoy a new lifestyle with my family. (Rod, 2012)

After extensive service older employees recognised the restructuring as an opportunity for VR and early-exit from wage labour. Hence financial packages constituted 'golden handshakes' with pay-outs rendering future plans more immediate.

In shaping agreeable outcomes, the actions of VR workers involved a degree of compliance with company plans to shed jobs and re-orient production around a more flexible workforce (Siemiatycki 2012). But VR workers also argued their actions had a moral, intra-labour grounding (Hastings 2016), supporting continued employment - and agency - of colleagues 'more needing of the 
job' (Harry, 2012). Using the lens of intra-labour agency, individual capacities to rework redundancy towards a lasting material benefit rested on a direct employment relationship and union bargained rights; residual skills coverage in work crews; acceptance of EOIs from managers; the timing of capital-initiated restructuring, and social factors such as age, time to planned retirement, financial positions of households, and lifestyle expectations (Gardiner et al. 2009). Nonetheless, such enabling factors weren't evenly applicable in the workforce with FR providing a very different set of workplace restructuring experiences.

\section{Forced redundancy}

In early 2012 nine participants were notified of FR (table 1). The mean age in the group was just 40 with an average service time of 15 years. Retrenchments focused in maintenance divisions of PKS, including skilled trades (boiler-makers, fitters) and lower-skilled labouring jobs. Collectively FR workers had substantial financial obligations with a high number of dependents $(n=21)$ and in all but one household were the main breadwinner. An ability to rework redundancy was highly constrained by social responsibilities and poor prospects for quick re-employment. After an open EOI period, workers in sections targeted for deeper cuts were informed of the number of jobs still needing to be reduced: 'a redundancy quota' (Julie 2015). FRs transpired when insufficient VRs were forthcoming.

In many sections of PKS sufficient VR applications were submitted, supporting job retention through redeployment. Still, shortfalls between quotas and 'volunteers' regularly occurred, instigating a 'competitive' intra-labour assessment process:

Three took VR in my crew [of 25], which left three to go. I couldn't take VR. I'm employed with a contractor so I'd get a few weeks extra pay. I wasn't remotely interested with a two year old, a mortgage, and wife in a part-time job. We relied [emphasises] on income from my job.

Anyway, we met on Monday afternoon and I got tapped on the shoulder. On Friday afternoon I was unemployed. Just like that. After ten years, I got five days' [notice]. (Mark, 2012) Typically, FR arrived suddenly and produced great shock. As the literature on plant downsizing has illustrated, when workers are given short notice of retrenchment they are deprived of valuable time to plan and prepare for re-employment (cf. Gardiner et al. 2009; MacKinnon 2017). Time is critical to securing positive outcomes. Sadly, within weeks of losing jobs and incomes workers and families were struggling; financially and emotionally. This reality was observed in the sale of homes, repossession of cars, schooling changes, relationship breakdowns, and poor mental health. The social turmoil also inhibited job searching, a finding also reaffirmed in other studies of retrenchment (see Weller 2012).

However, FR workers also revealed important insights into the nature of intra-labour negotiations in resolving redundancy shortfalls in workplaces. At PKS employees were effectively pitched against each other as managers (right-up hierarchies) reviewed skills, credentials, and job 
performance against new production requirements. Skills-based assessments replaced old 'seniority rules' but created an equally personal, divisive selection process for job retention vs. redundancy:

We fell four short in our processing crew [of 24]. Then the panic and arguing blew-up. Everyone went into self-protection mode. Four blokes in their late 50s wouldn't take VR. In the end, we were assessed, you know about it? A horrible process. Long story short, out of that I was retrenched. The worst part? I learned later from a manager we could've negotiated with raw materials, a section next to us. They'd too many VR applications but a unionised faction from the strip mill got in. Kept it quiet to suit several members. (Chad, 2012) The process of implementing FR was filled with intra-labour 'altercations and tensions' (Mehrotra 2017:263). Labour factions - union-non-union, workers-managers, direct-indirect - controlled information flows for strategic advantage (Stroud and Fairbrother 2012). Moreover, despite equal employment opportunity laws, skill-based assessments for managing redundancies were problematic in a stratified workplace. Skills training for programming, operating, servicing, and maintaining computerised control machinery was open to coercion. Overseen by line managers and 'leadinghands', not all workers in crews were notified of training sessions; were told they needed to organise training themselves, or 'couldn't attend sessions organised outside work because I have two young kids [to care for]' (Kylie, 2013). Employees with contractors also told how it was 'rare to talk about training [opportunities] because you're competing with each other for the best jobs' (Mark, 2013).

Internal divisions also broke along generational lines when older, financially secure workers retained jobs over younger colleagues deemed more needing of employment. An incident at a farewell event was instructive:

Eddy and Jim are in their early 60s and want to keep working. The boss said they can't discriminate because of age. But fuck, haven't they had their go? Worked 35 plus years; own several houses and would get massive payouts. Instead, they want a few more years. It's all they know. ... They turned up Friday night. You saw it? That just pissed a lot of us off. We went over and told them to fuck off. (2012)

Arguments and conflict became commonplace during the restructuring, particularly from those in secure financial positions and averse to VR and younger workers 'facing retrenchment with a lot more to lose' (Kylie, 2013). Younger workers who experienced FR (Mark, Chad, Glenn) felt they were forced to resourcefully manage 'the critical life event of redundancy' in a place with dwindling opportunities for industrial workers (Gardiner et al. 2009:728).

The unevenness of redundancy outcomes also mapped to intra-labour employment variations. Julie, Rodney, and Kylie had indirect employment relationships, receiving lower severance payments from employers holding multi-year maintenance contracts at PKS. Contract labour wasn't covered by union bargained EBAs (cf. Wills 2009), which over decades of labour-capital-state negotiations 
enshrined additional redundancy compensation above legal minimums. Employees of contractors received compensation under General Manufacturing Industry Awards, receiving up to $150 \%$ less than EBA workers labouring in the same workplace for the same period of time (table 2). Ultimately FR workers embodied the intra-labour inequities present in contemporary workplaces, articulating the need to ground labour agency in the everyday spatialities, politics, and relations of work (Gutelius 2015; Mehrotra 2017). Finally, I trace worker's longer-run re-employment experiences.

\section{Re-employment}

Labour research on plant closures and workplace downsizing shows that disparities in re-employment hinge on 'various enabling and constraining contextual factors' (Dobbins et al. 2013:517). These include individual aspirations, local job opportunities, and a willingness to relocate (Pike 2005). Generally, re-employment is made easier in buoyant regional economies executing long-term diversification policies (Bailey et al. 2014). By contrast, restructuring at PKS coincided with redundancies in local coal mines and stevedoring, inhibiting re-employment for displaced steelworkers. Regional jobs growth was focused in hospitality, retail, and aged-care sectors (ABS 2016). Participants were openly dismissive of such 'lower quality work that I'm unsuited too' (Glenn J 2013), arguing such jobs required prohibitive investments of time and money for retraining. Personal biographies thus aligned poorly to local job opportunities (Gardiner et al. 2009).

Four months after FR two fitters - Mark and Dale - were re-employed with a Sydney-based pharmaceutical firm. Time without jobs cost each family A \$20 thousand in lost wages but reemployment was on a permanent basis with incomes commensurate with old jobs. In both cases new employment was assisted by searching beyond the region and leveraging intra-labour relationships:

Dale and I went through [apprenticeships] with a big group. Hayden left a few years back to work for [firm] supervising their conveyors and pill machinery. The group from our apprenticeships, we keep in contact every few months. Hayden knew what was going on [at PKS] and told us about a few jobs coming-up. He put in good words and was a referee.... It's four months in and yeah, I'm happy. It's a cleaner workplace, conditions are good and it's permanent. That's big for us [be]cause Katie [partner] is casual and we've got a young daughter. The biggest issue is commuting. It's not sustainable long-term so there's a good chance we'll move at some point. (Mark, 2013)

Direct employment was 'an upgrade' from Mark's job at PKS. Yet, re-employment successes were tempered by 12 hours of weekly commuting, only mildly eased by car-pooling and nine-day fortnightly rosters. To be closer to work Mark and Dale moved to Sydney in 2014. As much as skills and credentials, their reworking agency displayed in sourcing new employment owed much too their social networks, including partners and family members performing the bulk of childcare and unpaid 
labour at home (Hanson and Pratt 1988; Katz 2004). Without geographical relocation both worker's agreed it was 'unlikely we could've secured such good jobs' (Dale, 2015).

For other retrenched workers employment beyond the region was ruled-out due to strong family and social ties to place (cf. Hudson and Sadler 1986; Weller 2012). Re-employment became a localised and longer-term struggle. On labour's side, workers submitted hundreds of failed job applications, engaged in retraining and attended interview coaching sessions. On the demand-side, government programs for business proved ineffective at creating quality new jobs locally (cf. Dobbins et al. 2013). In one example, a large tourism company received nearly $\mathrm{A} \$ 1 \mathrm{M}$ in grants for expansion of local services but after purchasing new equipment hired 21 weekend casuals. None were retrenched steelworkers. Unexpectedly losing jobs also had major impacts on self-confidence and mental health. Intra-labour care and support networks linked to the workplace were stripped away, triggering depression, anger, and anxiety among five workers that needed long-term medical treatment.

Despite personal challenges and labour market barriers, 24 months post-FR only one participant remained out of paid work: Gary 'gave-up finding a new job' and retired at 58. For others, re-employment converged around casualised work. In some perverse irony, six FR workers were reemployed back in PKS with two consolidated maintenance contractors. In a drive to reduce costs, the terms of maintenance outsourcing at PKS were re-written. Under the 'old' system that emerged from the 1980s restructuring, maintenance contracts were negotiated over three to five year periods, encouraging contractors to hire workers on a full-time basis to maintain workforce stability and drive productivity (Wills 2009). By comparison, a 'new' system asked contract firms to bid for short-term and individual jobs. As James explained, a workplace management culture 'that views maintenance as money-sinking and production as money-making was being driven to its extreme' (2014). Managers and staff operators planned and organised new work schedules, leading efforts to stretch the flexibility of maintenance workers to meet cost-savings targets and collect personal bonuses.

Under a reorganised maintenance process two large firms secured most of the outsourced jobs and actively recruited previously retrenched workers. As Chad said, 'they knew there's a pool of us anxious for work with experience fixing machinery that breaks-down a lot' (2015). PKS was remade around a sharper fault line of 'core' secure staff and insecure maintenance workers on the 'periphery':

I get calls in the evening or morning telling me if I've got work and in what section. I might get [told] the job and how long it's planned for. See, maintenance is organised around work orders that production staff issue. So, there's stretches of time without work and an income. And there's more distrust and anger around because staff think we should appreciate they've thrown us a bone. It's seriously hard to take. (Glenn J 2015)

On the surface, re-employment was an expression of worker's ability to recover from forced redundancy. Still, recovery was partial. Casualised new employment came with major trade-offs. 
Re-employment in casual maintenance-related jobs attracted slightly higher hourly rates of pay ('casual loading') compared to full-time, 'waged' employees. But this failed to compensate for the irregularity of work, removal of sick, holiday and long service leave, and protection from unfair dismissal. Re-employment equated to a $20-25 \%$ drop in monthly household incomes. For capital, restructuring delivered labour flexibility and savings that underpinned rising profitability. Between 2015 and 2017 the company enjoyed combined net profits of $\mathrm{A} \$ 1.3 \mathrm{~B}$; reduced net debt by $235 \%$; achieved a $33.5 \%$ return on investment, and witnessed a resurgent share price that rose $391 \%$ over the course of the research. Such 'strong results', Chairman John Bevan told shareholders, were 'because of a razor-sharp focus on cost competitiveness'.

A final point on re-employment. Labour geographers have a growing interest in the prevalence of precarious employment and the challenges that confront workers in flexible employment arrangements (cf. McDowell et al. 2009; Strauss 2017). In this case, precarious re-employment demanded reflexive actions to manage unstable livelihoods (cf. Bailey et al. 2014). Coping tactics included reducing expenditure on food, leisure and recreation, changing children's schooling, and selling possessions. In some cases, partners, usually women, 'squeezed more hours from my job to make-up for some lost income' (Kym, Chad's partner, 2015). As other labour studies indicate, resilience becomes socially necessary to cope with a critical event such as redundancy (cf. Gardiner et al. 2009; Dobbins et al. 2013). Yet, in longer struggles to resourcefully manage reduced incomes participants revealed how precariousness erodes socially, and why resilience must be approached critically by labour researchers who consider working people the key subjects of analysis.

Over time, insecure re-employment in the Illawarra strained once secure family relationships. Rodney and Karen's experience was both insightful and typical. Re-employed 17 months after FR, Rodney's 'new' income was insufficient to meet 'old' living costs. The family of five responded by selling their home, having fallen behind on the mortgage, and had since moved between rental properties. As Rodney chased more work, Karen took a second night job in a retail store:

I don't like complaining but it's, yeah. It's hard to be happy about life at the minute. We do our best keeping our heads above water. There's more stress though on the whole family because we live week-to-week trying to manage. I'm working a second job and Rodney's madly running around [for more work]. The kids are [pauses] have to do more and more on their own. Our lives have changed and it's very difficult. We're just coping. ... Our family, our relationships, they've been stretched to breaking-point. (Karen, 2016)

Other families impacted by reduced employment quality contended with similar 'battles to make ends meet' and 'maintain a decent life' (Craig, 2016). Demonstrating the new depths of intra-labour inequities, retrenched workers found new employment in old workplaces. Personal experiences and the everyday struggles of families spoke to why actions to 'make-do' are tough to sustain in place and 
over time without irreparably damaging social relationships, well-being, and living standards (cf. Hudson 2001; Strauss 2017). At the time of writing the army of casual, insecure workers presiding over PKS had grown to roughly 2500, about equal to the permanent workforce. In the restructuring wash-up, redundant were the stable full-time jobs not workers' skills and knowledge.

\section{Conclusions}

Labour geography is a project animated by hopes for a more egalitarian world of work and concerns with worsening inequities. Between these hopes and concerns, scholars are re-engaging with present cases of restructuring (Siemiatycki 2012; Werner 2012; Sweeney and Holmes 2013; Ince et al. 2015). As capitalist restructuring is reframed as a generative context for labour geographies, a dominant tendency to examine contestation and outcomes through the lens of labour unions is also shifting. To be clear, organised labour movements are vital for improving working conditions and living standards (Cumbers et al. 2016), as the historical evidence from PKS demonstrates. But incorporating lived experiences within the everyday spaces and places of work remains equally crucial to sharpen understandings of the shifting opportunities, struggles, divisions, and constraints facing workers and their communities (Coe and Jordhus-Lier 2011; Hastings and MacKinnon 2017). This article has sought a contribution towards grounded labour-centred research, developing intra-labour agency as an analytical lens to draw critical attention to uneven lived experiences and expressions of agency among workers within capitalist workplaces. To animate intra-labour agency the analysis focused on a recent case of restructuring in a stratified workplace that encompassed highly uneven workforce outcomes.

Connected to an accumulation strategy, capitalist restructuring is a relevant context for labour geography precisely because the process generates unequal socio-spatial effects (Bluestone and Harrison 1982; Massey 1984; Hudson 2001; Peck 2013). Unevenness is experienced across spaces and scales but also within workplaces and communities where labour is grounded and capacities to resist, rework, and resourcefully manage economic change are highly variable (Katz 2004). Intra-labour agency, as developed here, is intended to offer a frame for more deeply exploring the agency implications of labour's own internal divisions and fracture lines, experienced daily in workplaces and households. Engaging efforts to embed agency in the social and material contexts that enable and constrain its varied expressions (cf. Coe and Jordhus-Lier 2011; Hastings 2016), I've suggested intralabour agency can be usefully unpacked around a set of shaping dynamics encountered during a prolonged restructuring of Australia's largest industrial workplace. From PKS intra-labour agency was explored around the workplace structures positioning employees in labour processes, divisions, and hierarchies; prevailing co-worker relationships that shift over time along a spectrum and influence how workers see themselves in relation to others, and; social life matters beyond workplaces that shape outlooks and abilities to take certain courses of action. Deployed in dialogue with existing relational 
and spatio-temporal theorising of labour agency (Katz 2004; Coe and Jordhus-Lier 2011; Cumbers et al. 2016), intra-labour analyses can enrich labour geographies research concerned with the lived experiences of working people in their daily spaces and places of production and reproduction.

The empirical case utilised to elaborate intra-labour agency typifies many general outcomes of restructuring that unfold in workplaces organised around differentiated job tasks and work crews, internal hierarchies, and competition (Siemiatycki 2012; Hastings and MacKinnon 2017). In theorising across the 'landscape[s] of highly uneven political possibilities' labour encounters (Coe and Jordhus-Lier 2011:219), researchers are rightly concentrating on the various social arenas and institutional contexts where workers are differentially connected. Yet to date, intra-labour dynamics their role in alliance-building, strategising, and action-taking - have been a peripheral concern (Hastings 2016). This is politically and conceptually limiting. Capitalist workplaces are a key social arena for expressing agency, marked by diverse forms of politics and power relations among differentially positioned workers. Thinking through intra-labour agency brings into sharper focus the enabling and constraining effects within workplaces. As new labour processes and workplace control regimes emerge, so the potential for new intra-labour conflict and distrust may increase. But new opportunities for cooperation and alliance-building are also possible (cf. Rutherford 2010). The ongoing job for labour geographers is to uncover such possibilities, and towards this intra-labour agency provides a useful analytical frame.

On their own intra-labour analyses can't offer a complete explanation of labour's uneven experiences or capacities to shape capitalist landscapes. Workplace inequities emerge from structural inequities imposed by employers and buttressed by states. Labour's relative power, or lack thereof, is informed by the political economy of capital accumulation. However, as labour geographers have revealed over the past two decades, working people are 'multidimensional socio-spatial actors capable of modifying the conditions of their own existence' (Herod 2018:18). Both individual actions and collective labour movements draw power from intra-labour cooperation, unity, inclusion, trust, and respect (Gough 2010). Intra-labour agency is thus a frame to analyse the power relationships active within labour, interrogate how these are shaped by workplace structures, interactions and wider social life, and assess the implications for people and places.

\section{Acknowledgments}

I am sincerely grateful to the individuals and families that contributed time and energy to the research, often at a difficult period in their lives. I owe you all a huge debt I fear I can't repay. Thank you to Chantel Carr, Chris Gibson and other wonderful colleagues at the University of Wollongong for comments on an earlier draft. Thanks also to editor Tariq Jazeel and the five anonymous referees for constructive feedback and support that helped improve the article. All remaining errors are my own.

\section{Notes}

1: In FY2017 BlueScope's total external revenue was A $\$ 10.7$ billion. 
2: The term restructuring is polysemous. It is used as a descriptive for economic changes occurring at various sites and scales; as a relational analytical category to 'get behind' causality, and; as a frame for institutional, regulatory and policy changes choreographed by private enterprise, states, and labour unions in reforming accumulation strategies.

3: Before the labour geography 'moment' feminist geographers led the way in charting new directions for labour-related inquiry. Focus was both inside paid labour markets, where women achieved greater access to service sector jobs (Massey 1984; McDowell 1991), and connected spheres of social reproduction on which capitalism depends and women do most of the work (cf. Hanson and Pratt 1988). Herod (1997; 2001) built a project for centring labour's agency in analysis.

4: During the research several workers were warned by managers against speaking to the researcher and threatened with disciplinary action if caught doing so. A draft manuscript was shown to participants for comment.

5: Workers used 'redundancy' and 'retrenchment' interchangeably.

\section{References}

Australian Bureau of Statistics (ABS). 2016. Characteristics of Employment, Australia. Cat no. 6333.0, Canberra: ABS.

Bailey, D., Bentley, G., de Ruyter, A. and Hall, S. 2014. Plant Closures and Taskforce

Responses. Regional Studies, Regional Science 1(1):60-78.

Bair, J. and Werner, M. (2017) New Geographies of Uneven Development in Global

Formation: Thinking with Chase-Dunn. Journal of World-Systems Research 22(2):604-619.

Bluestone, B., and Harrison, B. 1982. The Deindustrialization of America. New York: Basic.

Brogan, P. and Tufts, S. 2017. Labor geography. In D Richardson et al. (eds.). The

International Encyclopedia of Geography. Wiley Online, DOI: 10.1002/9781118786352.

Buckley, M., McPhee, S., and Rogaly, B. 2017. Labour geographies on the move: Migration, migrant status and work in the 21st century. Geoforum 78(2):153-158.

Burawoy, M. 1979 Manufacturing Consent. Chicago: University of Chicago Press.

Burrows, S. 2012. Unemployment in the Illawarra Region. Journal of the Illawarra Branch of the Aust Soc for Labour History 11(1):51-66.

Carr, C. 2017. Maintenance and repair beyond the perimeter of the plant: linking industrial labour and the home. Trans Inst Br Geogr 42(4):642-654.

Carswell, G. De Neve, G. 2013. Labouring for global markets: Conceptualising labour agency in global production networks. Geoforum 44(1):62-70.

Castree, N. 2007. Labour geography: a work in progress. International Journal of Urban and Regional Research 31(4):853-862.

Castree, N., Coe, N.M., Ward, K. and Samers, M. 2004. Spaces of work. London: Sage.

Coe, N. M. and Jordhus-Lier, D. 2011. Constrained Agency? Re-Evaluating the Geographies of Labour. Progress in Human Geography 35(2):211-233.

Commonwealth Conciliation and Arbitration Act. 1904. no. 13. Available: https://www.legislation.gov.au/Details/C2004C02998 (Accessed 12 March 2014)

Cooper, R. and Ellem, B. 2008. The neoliberal state, trade unions and collective bargaining in Australia. British Journal of Industrial Relations 46(3):532-554.

Cumbers, A., Helms, G. and Swanson, K. 2010. Class, agency and resistance in the old industrial city. Antipode 42(1):46-73.

Cumbers, A. et al. 2016. Intervening in globalization: the spatial possibilities and institutional barriers to labour's collective agency. Journal of Economic Geography 16(1)93-108.

Dobbins, T. et al. 2014. 'Make do and mend' after redundancy at Anglesey Aluminium: critiquing human capital approaches to unemployment. Work, Employment, and Society 28:515-532.

Eklund, E. 2002. Steel Town: The Making and Breaking of Port Kembla. Melbourne: MUP.

Ellem, B. 2016. Geographies of the Labour Process: Automation and the Spatiality of Mining'. Work, Employment and Society 30(6):932-948.

Ellen-Smith, B. and Winders, J. 2008. We're here to stay: Economic restructuring, Latino migration, and place-making in the US south. Trans Inst Br Geogr 33(1):60-72.

Featherstone, D. and Griffin, P. 2016. Spatial relations, histories from below and the makings of agency. Progress in Human Geography 40(3):375-393. 
Gardiner, J., Stuart, M., MacKenzie, R., Forde, C., Greenwood, I. and Perrett, R. 2009. Redundancy as a critical life event: moving on from the Welsh steel industry through career change. Work Employment \& Society 23(4): 727-745.

Gialis, S. and Herod, A. 2014. Of steel and strawberries: Greek workers struggle against informal and flexible working arrangements during the crisis. Geoforum 57(2):138-149.

Gibson, C., Carr, C., and Warren, A. 2012. A Country that Makes Things? Australian Geographer 43(2): 109-113.

Gough, J. 2010. Worker's strategies to secure jobs, their uses of scale, and competing economic moralities: rethinking the 'geography of justice'. Political Geography 29(2):129-139.

Gutelius, B. 2015. Disarticulating distribution: Labor segmentation and subcontracting in global logistics. Geoforum 60(1):53-61.

Hanson, S. and Pratt, G. 1988. Reconceptualising the links between home and work in urban geography. Economic Geography 64(4):299-321.

Harvey, D. 1982. The Limits to Capital. Chicago: University of Chicago Press.

Hastings, T. 2016. Moral matters: De-romanticising labour agency and charting new directions in labour geography. Geography Compass 10(7):307-318.

Hastings, T. and MacKinnon, D. 2017. Re-embedding agency at the workplace scale: Workers and labour control at Glasgow call centres. Environment and Planning A 49(1):104-210.

Haughton, G. 1990. Community and industrial restructuring: responses to the recession and its aftermath in the Illawarra region of Australia. Environment and Planning A 21(2):233-247.

Herod, A. 1997. From a geography of labour to a labour geography. Antipode 29(1):1-31.

Herod, A. 2001. Labour Geographies. London: Guildford.

Herod, A. 2018. Labor. Cambridge: Polity Press.

Hudson, R. and Sadler, D. 1986. Contesting works closures in Western Europe's old industrial regions. In A J Scott and M Storper (eds) Production, Work and Territory: The Geographical Anatomy of Industrial Capitalism, pp. 172-194. Allen \& Unwin: London.

Hudson, R. 2001. Producing Places. New York: Guildford.

Ince, A., Featherstone, D., Cumber, A., MacKinnon, D. and Strauss, K. 2015. British Jobs for British Workers? Negotiating Work, Nation, and Globalisation through the Lindsey Oil Refinery Disputes. Antipode 47(1):139-157.

International Labour Organization (ILO). 2015. World Employment Social Outlook: The Changing Nature of Jobs. Geneva: ILO Research Department.

Katz, C. 2004. Growing-up Global: Economic Restructuring and Children's Everyday Lives. Minneapolis: University of Minnesota Press.

MacKinnon, D. 2017. Labour branching, redundancy and livelihoods: Towards a more socialised conception of adaptation in evolutionary economic geography. Geoforum 79(1):70-80.

Massey, D. 1984. Spatial divisions of labour: social structures and the geography of production. Basingstoke: Macmillan.

McDowell, L. 1991. Life without Father and Ford: The New Gender Order of Post-Fordism. Transactions of the Institute of British Geographers 16(4):400-419.

McDowell, L., Batnitzky, A., and Dyer, S. 2009. Precarious work and economic migration: Emerging immigrant divisions of labour in Greater London's service sector. IJURR 33(1):3-25.

Mehrotra, I. 2017. Subsidising capitalism and male labour: The scandal of unfree Dalit female labour relations. In S Anandhi and K. Kapadia (eds) Dalit women: Vanguard of an alternative politics in India. New York: Routledge, pp. 246-276.

Mitchell, D. 2011. Labor's geography: capital, violence, guest workers and the post-World War II landscape. Antipode 43(2):563-595.

Peck, J. 1996. Work-Place: The Social Regulation of Labor Markets. New York: Guildford.

Peck, J. 2013. Making space for labour. In D. Featherstone and J. Painter (eds) Spatial Politics: Essays for Doreen Massey. London: Wiley \& Sons, pp. 99-114.

Pike, A. 2005. Building a Geographical Political Economy of Plant Closure. Antipode 37(1):93-115. 
Rainnie, A., Herod, A. and McGrath-Champ, S. 2007. Spatializing Industrial Relations. Industrial Relations Journal 38(2):102-118.

Rutherford, T. 2010. De/Re-centring work and class? A review and critique of labour geography. Geography Compass 4(7):768-777.

Siemiatycki, E. 2012. Forced to concede: permanent restructuring and labour's place in the North American auto industry. Antipode 44(2):453-473

Strauss, K. 2017. Labour geography I: Towards a geography of precarity? Progress in Human Geography, 42(4):622-630.

Stroud, D. and Fairbrother, P. 2012. The limits and prospects of union power: Addressing mass-redundancy in the steel industry. Economic and Industrial Democracy 33(4):649-668.

Sweeney, B. and Holmes, J. 2013. Problematizing Labour's Agency: Rescaling Collective Bargaining in British Columbia Pulp and Paper Mills. Antipode 45(1):218-237.

Tonkin, L. 2000. Women of steel: constructing and contesting new gendered geographies of work in the Australian steel industry. Antipode 32(2):115-134.

Warren, A. 2014. Working Culture: The Agency and Employment Experiences of NonUnionized Workers in the Surfboard Industry. Environment and Planning A 46(10):2300-2316.

Weller, S. 2007. Power and Scale: The shifting relations of Industrial Relations Law in Australia. Antipode 39(5):896-919.

Weller, S. 2012. Financial stress and the long-term outcomes of job loss. Work, Employment and Society 26(1):10-25.

Werner, M. 2012. Beyond Upgrading: Gendered Labor and the Restructuring of Firms in the Dominican Republic. Economic Geography 88(4):403-422.

Wills, J. 2009. Subcontracted employment and its challenge to labor. Labor Studies Journal 34(4):441-460. 